Issue 1 (Agustus, 2018)

https://doi.org/10.31227/osf.io/rfsyx

\title{
Pengaruh Pemberdayaan Terhadap Kepuasan Kerja Melalui Komitmen Organisasional
}

\author{
Muhammad Hidayat Taufik ${ }^{1)}$, Herman Sjahruddin 2), Nurlaely Razak ${ }^{3)}$ \\ Muhhidayattaufik@gmail.com
}

1) Mahasiswa Program Studi Manajemen pada Sekolah Tinggi Ilmu Ekonomi Bongaya Makassar

2,3) Dosen Program Studi Manajemen pada Sekolah Tinggi Ilmu Ekonomi Bongaya Makassar

\begin{abstract}
ABSTRAK
Penelitian ini bertujuan untuk menguji dan menganalisis pengaruh pemberdayaan terhadap kepuasan kerja melalui komitmen organisasional karyawan pada PT. Pelindo IV (Persero) Cabang Terminal Petikemas Makassar. Pengumpulan data menggunakan data primer yang diperoleh dari kuesioner. Populasinya adalah karyawan PT. Pelindo IV (Persero) Cabang Terminal Petikemas Makassar yang berjumlah 158 karyawan, sedangkan sampel yang diambil hanya 55 orang responden. Hasil pengujian Structural Equation Modeling (SEM) WarpPLS versi, 5.0. memberikan bukti bahwa pemberdayaan berpengaruh positif dan signifikan terhadap komitmen organisasional, pemberdayaan berpengaruh positif dan signifikan terhadap kepuasan kerja, komitmen organisasional berpengaruh positif dan signifikan terhadap kepuasan kerja, pemberdayaan berpengaruh positif dan signifikan terhadap kepuasan kerja melalui komitmen organisasional karyawan
\end{abstract}

Kata kunci : $\begin{aligned} & \text { Pemberdayaan, Kepuasan Kerja dan Komitmen } \\ & \text { Organisasional }\end{aligned}$

\section{ABSTRACT}

This study is to determine the influence of Empowerment on Job Satisfaction. As a mediating role of Organizational Commitment at PT.Pelindo IV (Persero). The population of this study was all of the employees at PT. Pelindo IV (Persero). It was 158 employees. The sample of this study was consisted of 55 respondents. The analysis in testing hypothesis used Structural Equation Modeling (SEM) with WarpPLS Assistance 5.0. The result of this study showed that empowerment had the positive and significant on organizational commitment, empowerment had the positive and significant on job satisfaction, organizational commitment had the positive and significant on job satisfaction and empowerment had the positive and significant on job satisfaction. As a mediating role with organizational commitment.

Authors : Muhammad Hidayat Taufik dkk. Issue 1 (Agustus, 2018); 82 98 


\section{JURNAL ORGANISASI DAN MANAJEMEN}

Issue 1 (Agustus, 2018)

https://doi.org/10.31227/osf.io/rfsyx

Keywords: Empowerment, Job Satisfaction, Organizational Commitment

\section{Latar Belakang}

Persaingan dan perubahan dunia bisnis menuntut perusahaan agar beradaptasi dengan perkembangan yang terjadi melalui pengelolaan perusahaan secara efisien dan efektif. Persoalan yang di hadapi perusahaan umumnya adalah adanya faktorsikap dan perilaku karyawan yang tidak dapat dikendalikan dalam proses pengelolaan sumber daya manusia sehingga berdampak pada rendahnya kepuasan kerja karyawan (Sukrajap, 2017).

Penjelasan tentang kepuasan kerja dalam penelititan ini merujuk pada teori dua faktor (two factor theory) juga dikenal sebagai teori motivasi Herzberg atau teori hygiene-motivator Teori ini dikembangkan oleh Frederick Irving Herzberg (1923), bahwa faktor-faktor penentu di tempat kerja yang menyebab kanterjadinya kepuasan dan ketidak puasan kerja, yaitu faktor pemeliharaan (maintenance factors) dan faktor motivasi (motivation factors). Faktor pemeliharaan atau disebut pula dissatifiers, hygiene factors, job context, extrinsic factors meliputi administrasi dan kebijakan perusahaan, kualitas pengawasan, hubungan dengan pengawas, hubungan dengan subordinate, upah, keamanan kerja, kondisi kerja dan status. Sedangkan faktor pemotivasian disebut pula satisfier, motivators, job content, intrinsic factors meliputi dorongan berprestasi, pengenalan, kemajuan (advancement), work it self, kesempatan berkembang dan tanggung jawab (Ringgio, 2007; dalam Hurriyati, D. 2018).

Berdasarkan two factor theory tersebut dapat dijelaskan bahwa tinggi rendahnya kepuasan kerjakaryawan disebabkan karena faktor pemeliharaan (hygiene factors / dissatisfier), yang dalam penelitian ini dicirikan melalui komitmen organisasional sedangkan faktor pemotivasian (satisfier), dalam penelitian ini ditunjukkan melalui variabel pemberdayaan karyawan.

Beberapa ciri-ciri karyawan yang memiliki kepuasan kerja yang tinggi merasa senang melakukan tugas dalam pekerjaanya, yaitu dengan dating tepatwaktu tidak terlambat dan melaksanakan apel pagi dan setelah itu melaksanakan tugas pada unit kerjanya masing-masing (komitmen organisasional). Sedangkan ciri-ciri karyawan yang tidak puasa dalah mereka yang malas berangkat ketempat bekerja dan malas dengan pekerjaanya (pemberdayaan karyawan). Ciri-ciri perilaku karyawan yang memiliki kepuasan kerjaan taralain, tingkah laku karyawan yang malas tentunya akan menimbulkan masalah berupa tingkat absensi yang tinggi, keterlambatan kerja, dan pelanggaran disiplin yang lainnya (Ringgio, 2009; dalam Hurriyati, 2018).

Salah satu faktor yang mempengaruhi kepuasan kerja karyawan adalah faktor pemberdayaan. Pemberdayaan sebagai suatu proses untuk menjadikan karyawan untuk menjadi lebih berdaya atau lebih berkemampuan dalam menyelesaikan masalahnya sendiri dengan cara memberikan kepercayaan dan kewenangan sehingga menumbuhkan rasa tanggung jawabnya (Wibowo, 2012:409).

Halaman 83

Authors : Muhammad Hidayat Taufik dkk. Issue 1 (Agustus, 2018); 82 98 


\section{JURNAL ORGANISASI DAN MANAJEMEN}

Issue 1 (Agustus, 2018)

\section{https://doi.org/10.31227/osf.io/rfsyx}

Pemberdayaan karyawan yang baik (tinggi) dapat dilihat dengan beberapa indikator, yaitu : (1) motivasidiri yang tinggi; (2) memiliki pengertiant erhadap pekerjaan dan keahlian yang lebih; (3) kepercayaandiri; (4) Inisiatif yang tinggi; (5) mempunyai otonomi dan kemampuan; (6) produktifitas kerja yang tinggi; (7) bertanggung jawab untuk bertindak; dan, (8) memecahkan masalah. (Tjiptono, 2006; dalam Febriwanti dkk., 2017).

Hasil penelitian terdahulu bukti menunjukkan bahwa pemberdayaan psikologis karyawan memiliki pengaruh positif dan signifikan terhadap kepuasan kerja (Akbar, et al. 2011; Khera, 2015; Naeem, 2013). Hasil ini tidak sejalan dengan temuan penelitilainnya, bahwa pemberdayaan memiliki pengaruh negative dan signifikan terhadap Kepuasan Kerja (Samiun dkk., 2017).

Fakta lapangan terkait pemberdayaan karyawan pada PT. Pelindo IV (Persero) Cabang Terminal Petikemas Makassar menunjukkan bahwat erdapat beberapa karyawan yang berdasarkan kepangkatan dan senioritasnya seharusnya dilibatkan atau di ikutkan untuk berparsitifasi dalam beberapa kegiatan penting yang dilakukan perusahaan, namun faktanya bahwa umumnya karyawan yang dilibatkan dalam kegiatan perusahaan tersebut adalah karyawan yang berdasarkan kepangkatannya belum memenuhi persyaratan untuk dilibatkan (diberdayakan). Pemberdayaan karyawan pada PT. Pelindo IV Cabang (Persero) Terminal Petikemas Makassar dalam beberapa kesempatan hanya di dasari pada faktor kedekatan emosional semata tidak berdasarkan kepangkatan atau peraturan dan ketentuan yang berlaku.

Pemberdayaan karyawan yang tinggi mengakibatkan tingginya kepuasan kerja karyawan, namun terdapat juga faktor lainnya, yaitu komitmen organisasional. Komitmen organisasional (organizational commitment) merupakan tingkat keyakinan karyawan untuk menerima tujuan organisasi sehingga berkeinginan untuk tetap tinggal dan menjadi bagian dari organisasi tersebut (Sopiah, 2008). Hasil penelitian terdahulu membuktikan bahwa komitmen organisasional berpengaruh positif dan signifikan terdahap kepuasan kerja (Arishanti, 2011). Temuan tersebut memperoleh bantahan dari penelitilainnya, komitmen organisasional berpengaruh negatif dan tidak signifikan terhadap kepuasan kerja (Nongkeng, 2011).

Semakin tinggi pemberdayaan, maka semakin tinggi komitmen organisasional dan kepuasan kerja karyawan (Tania dan Eddy 2013). Pernyataan tersebut dapat dimaknai bahwa komitmen organisasional bertindak sebagai variable intervening (mediasi) dalam menganalisis pengaruh pemberdayaan terhadap kepuasan kerja. Hal ini dapat dilakukan karena pada penelitian terdahulu ditemukan bahwa komitmen organisasional terbukti sebagai variabel pemediasi dalam menganalisis pengaruh pemberdayaan terhadap kepuasan kerja. Pemberdayaan berpengaruh positif dan signifikan terhadap kepuasan kerja melalui komitmen organisasional (Tania dan Eddy 2013). Hasil berbeda ditujukan oleh peneliti lainnya bahwa pemberdayaan berpengaruh negative dan signifikan terhadap Kepuasan Kerja (Samiun dkk., 2017) dan komitmen organisasional berpengaruh negatif dan tidak signifikan terhadap kepuasan kerja (Nongkeng, 2011).

Authors : Muhammad Hidayat Taufik dkk. Issue 1 (Agustus, 2018); 82 98

Halaman 84 


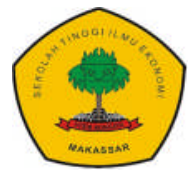

JURNAL ORGANISASI DAN MANAJEMEN

Issue 1 (Agustus, 2018)

https://doi.org/10.31227/osf.io/rfsyx

Kepuasan kerja karyawan PT. Pelindo IV (Persero) Cabang Terminal Petikemas Makassar berdasarkan hasil pra-penelitian menunjukkan bahwa masih terdapat karyawan yang malas dalam bekerja dan tingkat kehadiran karyawan yang rendah serta pada beberapa kasus ditemukan masih terdapatnya karyawan yang datang terlambat dalam bekerja disebabkan karena karyawan tidak diberdayakan dengan baik serta harapan karyawan untuk memperoleh peningkatan penghasilan dari beberapa pekerjaan yang mereka lakukan terbukti tidak sesuai dengan kenyataan yang mereka peroleh sehingga menjadi penyebab rendahnya kepuasan kerja karyawan.

\section{Tinjauan Teoritis}

\section{Pemberdayaan}

Pemberdayaan sebagai suatu proses untuk menjadikan orang menjadi lebih berdaya atau lebih berkemampuan untuk menyelesaikan masalahnya sendiri dengan cara memberikan kepercayaan dan kewenangan sehingga menumbuhkan rasa tanggung jawabnya. Kreatifitas, fleksibilitas atas pekerjaan sendiri dapat terbentuk dari proses pemberdayan karyawan hal ini akan menunjang potensi yang ada didalam diri karyawan dalam menyelesaikan tugasnya (Wibowo.,2012; dalam Mahiri, 2017). Definisi lainnya menjelaskan mengatakan pemberdayaan merupakan sebuah proses yang menekankan bahwa orang memperoleh keterampilan, pengetahuan, dan kekuasaan yang cukup mempengaruhi kehidupannya dan kehidupan orang lain yang menjadi perhatiannya Edi Suharto (2005: 58). Pemberdayaan karyawan (employee empowerment) berarti memberikan kesempatan kepada karyawan untuk membuat keputusan yang berkaitan dengan pekerjaannya untuk memberi otonomi yang lebih luas kepada karyawan. Untuk menentukan tugas dan pekerjaan yang harus dikerjakan sesuai inisiatifnya sepanjang tidak berlawanan dengan tujuan yang hendak dicapai oleh organisasi (Noe et.al., dalam; Dewi, 2003).

\section{Komitmen Organisasional}

Komitmen adalah kemampuan dan kemauan untuk menyelaraskan perilaku dengan kebutuhan, prioritas dan tujuan organisasi. Hal ini mencakup cara-cara mengembangkan tujuan atau memenuhi kebutuhan organisasi yang intinya mendahulukan misi organisasi dari pada kepentingan pribadi Soekidjan (2009:43). Definisi lainnya menjelaskan komitmen organisasional adalah tingkat sampai dimana karyawan yakin dan menerima tujuan organisasional, serta berkeinginan untuk tinggal bersama organisasi tersebut. Disimpulkan bahwa komitmen organisasi merupakan penerimaan individu terhadap nilai-nilai dan tujuan organisasi, dan individu yang berupaya, berkarya dan memiliki hasrat kuat untuk tetap bertahan dalam organisasi tersebut (Mathis, dan Jackson, 2004; dalam Tilaar, 2014).

\section{Konsep Kepuasan Kerja (karyawan)}

Authors : Muhammad Hidayat Taufik dkk. Issue 1 (Agustus, 2018); 82 98 


\section{JURNAL ORGANISASI DAN MANAJEMEN}

Issue 1 (Agustus, 2018)

\section{https://doi.org/10.31227/osf.io/rfsyx}

Terdapat dua faktor menyebabkan terjadinya kepuasan dan ketidakpuasan kerja Herzberg atau teori hygiene-motivator (Ringgio, 2007; dalam Hurriyati, D. 2018), yaitu:

1) Faktor pemeliharaan (maintenance factors) atau disebut pula dissatifiers, hygiene factors, job context, extrinsic factors meliputi administrasi dan kebijakan perusahaan, kualitas pengawasan, hubungan dengan pengawas, hubungan dengan subordinate, upah, keamanan kerja, kondisi kerja dan status.

2) Faktor motivasi (motivation factors)disebut pula satisfier, motivators, job content, intrinsic factors meliputi dorongan berprestasi, pengenalan, kemajuan (advancement), work it self, kesempatan berkembang dan tanggung jawab.

Kepuasan kerja (job satisfaction) adalah cara individu merasakan pekerjaannya yang dihasilkan dari sikap individu tersebut terhadap berbagai aspek yang terkandung di dalam pekerjaan Suwatno dan Priansa (2011). Definisi lainnya menjelaskan kepuasan kerja adalah hasil dari persepsi karyawan mengenai seberapa baik pekerjaan mereka memberikan hal yang dianggap penting (Luthans, 2006).

\section{Metode Penelitian}

Pendekatan dalam penelitian ini adalah pendekatan kuantitatif dengan explanatory survey yaitu penelitian yang mengambil sampel dari suatu populasi yang di teliti dan menjelaskan hubungan atau kausalitas antara variabel-variabel yang akan melalui pengujian hipotesis. Penelitian ini menggunakan pendekatan kuantitatif yang datanya berwujud pada bilangan (angka-angka) dan pembuktian hipotesis yang dilakukan menggunakan analisis statistik (Sugiyono, 2013:13).

\section{Hasil Penelitian}

\section{Evaluasi Model Pengukuran (Outer Model) Model 1}

Terdapat 3 kriteria dalam analisis evaluasi model yaitu, convergent validity, discriminant validity dan composite reliability. Berikut ini adalah hasil analisis data pada WarpPLS:

\section{a. Convergent Validity}

Convergent validity dari model pengukuran dapat dilihat dari korelasi antara skor indikator dengan skor konstruknya (loading factor). suatu model dikatakan baik dan memenuhi pengujian Convergent Validity apabila nilai loading faktor dari setiap indikator $\geq 0,70$ dan nilai $p$-value $<0,05$ dianggap signifikan. Pada beberapa kasus, syarat loading di atas 0.70 sering tidak terpenuhi khususnya untuk kuesioner yang baru dikembangkan. Oleh karena itu, loading antara 0.40-0.70 harus tetap dipertimbangkan untuk dipertahankan.Selanjutnya dijelaskan pula bahwa, indikator dengan loading< 4.50 dihapus dari model.Penghapusan indikator dengan loading antara 0.40- 


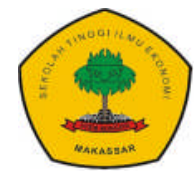

JURNAL ORGANISASI DAN MANAJEMEN

Issue 1 (Agustus, 2018)

https://doi.org/10.31227/osf.io/rfsyx

0.70 dilakukan apabila indikator tersebut dapat meningkatkan AVE dan composite reliability diatas nilai batasannya. Nilai batasan untuk AVE 0,50 dan composite reliability adalah 0,50 (Machfud dan Dwi, 2013: 66 dalam Arista, 2015).Hasil pengolahan Convergent validity dalam pengujian WarpPLS Versi 5.0 dapat di jelaskan pada tabel berikut:

Tabel 1. Convergent Validity

\begin{tabular}{|c|l|c|c|c|c|}
\hline Variabel & \multicolumn{1}{|c|}{ Convergent Validity } & PBD & KO & KK & P value \\
\hline \multirow{4}{*}{ Pemberdayaan } & Arti Pekerjaan $\left(\mathrm{X}_{11}\right)$ & $(0.637)$ & -0.056 & 0.069 & $<0.001$ \\
\cline { 2 - 6 } & Kompetensi $\left(\mathrm{X}_{12}\right)$ & $(0.791)$ & 0.074 & -0.178 & $<0.001$ \\
\cline { 2 - 6 } & Pengaruh Diri Sendiri $\left(\mathrm{X}_{13}\right)$ & $(0.598)$ & 0.496 & -0.239 & $<0.001$ \\
\cline { 2 - 6 } & Dampak $\left(\mathrm{X}_{14}\right)$ & $(0.817)$ & -0.392 & 0.294 & $<0.001$ \\
\hline \multirow{4}{*}{$\begin{array}{c}\text { Komitmen } \\
\text { Organisasional }\end{array}$} & Komitmen Afektif $\left(\mathrm{Y}_{11}\right)$ & 0.507 & $(0.718)$ & -0.167 & $<0.001$ \\
\cline { 2 - 6 } & Komitmen Berkelanjutan( $\left.\mathrm{Y}_{12}\right)$ & -0.318 & $(0.788)$ & 0.071 & $<0.001$ \\
\cline { 2 - 6 } & Komitmen Normative $\left(\mathrm{Y}_{13}\right)$ & -0.153 & $(0.741)$ & 0.087 & $<0.001$ \\
\hline \multirow{4}{*}{$\begin{array}{c}\text { Kepuasan } \\
\text { Kerja }\end{array}$} & Kepuasan Finansial $\left(\mathrm{Y}_{21}\right)$ & -0.193 & -0.109 & $(0.749)$ & $<0.001$ \\
\cline { 2 - 6 } & Kepuasan Fisik $\left(\mathrm{Y}_{22}\right)$ & 0.068 & 0.247 & $(0.708)$ & $<0.001$ \\
\cline { 2 - 6 } & Kepuasan Sosial $\left(\mathrm{Y}_{23}\right)$ & -0.192 & 0.399 & $(0.616)$ & $<0.001$ \\
\cline { 2 - 6 } & Kepuasan Psikologi $\left(\mathrm{Y}_{24}\right)$ & 0.263 & -0.415 & $(0.817)$ & $<0.001$ \\
\hline
\end{tabular}

Sumber: Data diolah (WarpPLS versi 5.0, 2018).

Berdasarkan hasil pengolahan data pada tabel 1 maka dapat di jelaskan sebagai berikut:

1) Convergent Validity untuk konstruk pemberdayaan, bahwa dari 4 indikator pemberdayaan, yaitu untuk indikator $\mathrm{X}_{11}$ dan $\mathrm{X}_{13}$ tidak di keluarkan dari model karena merujuk pada pendapat (Hasanuddin, R., \& Sjahruddin, H. 2017) nilai standarized loading factor di atas 0,5 dapat diterima, sedangkan di bawah 0,5 dikeluarkan dari model. Sehingga tidak ada alasan yang kuat untuk mengeluarkan indikator tersebut. Sedangkan indikator $\mathrm{X}_{12}$ dan $\mathrm{X}_{14}$, semua indikator tersebut memenuhi standar Convergent Validity dengan nilai $>0.70$, sehingga indikator-indikator tersebut tidak dikeluarkan.

2) Convergent Validity untuk konstruk komitmen organisasional, bahwa dari 3 indikator komitmen organisasional, yaitu $Y_{11}, Y_{12}$, dan $Y_{13}$ semua indikator tersebut memenuhi standar Convergent Validity dengan nilai $>0.70$, sehingga indikator-indikator tersebut tidak dikeluarkan.

3) Convergent Validity untuk konstruk kepuasan kerja, bahwa dari 4 indikator kepuasan kerja, yaitu untuk indikator $\mathrm{Y}_{23}$ tidak di keluarkan dari model karena merujuk pada pendapat (Hasanuddin dan Sjahruddin, 2017) nilai standarized loading factor $>0,60$ dapat diterima, sedangkan

Authors : Muhammad Hidayat Taufik dkk. Issue 1 (Agustus, 2018); 82 98 


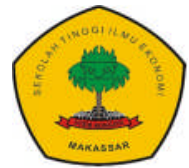

Issue 1 (Agustus, 2018)

https://doi.org/10.31227/osf.io/rfsyx

jika $<0,5$ dikeluarkan dari model. Sehingga tidak ada alasan yang kuat untuk mengeluarkan indikator tersebut. Sedangkan indikator $\mathrm{Y}_{21}, \mathrm{Y}_{22}$ dan $\mathrm{Y}_{24}$, semua indikator tersebut memenuhi standar Convergent Validity dengan nilai $>0.60$, sehingga indikator-indikator tersebut tidak dikeluarkan.

\section{b. Discriminant Validity (Validitas Diskriminan)}

Pengujian selanjutnya seletelah Convergent Validity yaitu Dicriminant Validity. suatu konstruk dikatakan baik apabila telah memenuhi syarat validitas diskriminan yaitu, hasil dalam view combined loading and crossloadings menunjukkan bahwa loading ke konstruk lain (cross-loading) bernilai lebih rendah daripada loading ke konstruk variabel (Wijayanti, W. S., dkk. 2017). Hasil pengujian Dicriminant Validity dapat di lihat pada tabel berikut.

Tabel 2. Discriminant Validity

\begin{tabular}{|l|c|c|c|}
\hline \multirow{2}{*}{ Discriminant Validity } & \multicolumn{3}{|c|}{ Nilai Loading ke Konstruk Lain } \\
\cline { 2 - 4 } & PBD & KO & KK \\
\hline Arti Pekerjaan $\left(\mathrm{X}_{11}\right)$ & $(0.637)$ & -0.056 & 0.069 \\
\hline Kompetensi $\left(\mathrm{X}_{12}\right)$ & $0.791)$ & 0.074 & -0.178 \\
\hline Pengaruh Diri Sendiri $\left(\mathrm{X}_{13}\right)$ & $0.598)$ & 0.496 & -0.239 \\
\hline Dampak $\left(\mathrm{X}_{14}\right)$ & $0.817)$ & -0.392 & 0.294 \\
\hline Komitmen Afektif $\left(\mathrm{Y}_{11}\right)$ & 0.507 & $0.718)$ & -0.167 \\
\hline Komitmen Berkelanjutan $\left(\mathrm{Y}_{12}\right)$ & -0.318 & $0.788)$ & 0.071 \\
\hline Komitmen Normative $\left(\mathrm{Y}_{13}\right)$ & -0.153 & $0.741)$ & 0.087 \\
\hline Kepuasan Finansial $\left(\mathrm{Y}_{21}\right)$ & -0.193 & -0.109 & $0.749)$ \\
\hline Kepuasan Fisik $\left(\mathrm{Y}_{22}\right)$ & 0.068 & 0.247 & $0.708)$ \\
\hline Kepuasan Sosial $\left(\mathrm{Y}_{23}\right)$ & -0.192 & 0.399 & $0.616)$ \\
\hline Kepuasan Psikologi $\left(\mathrm{Y}_{24}\right)$ & 0.263 & -0.415 & $0.817)$ \\
\hline Sumber Data diolan $\left(\mathrm{W}_{2}\right)$ & & & \\
\hline
\end{tabular}

Sumber: Data diolah (WarpPLS versi 5.0, 2018).

Model di tabel 2 telah di jelaskan sebelumya bahwa seluruh indikator tersebut telah memenuhi standar Convergent Validity, sehingga dilanjutkan pada pengujian Dicriminant Validity, pada pengujian Dicriminant validity dapat disimpulkan bahwa semua indikator tersebut telah memenuhi standar dicriminant validity dimana nilai loading ke konstruk lain lebih rendah dibanding nilai loading ke konstruknya sendiri pada kolom yang sama.

\section{c. Composite Reliability}

Pengujian selanjutnya adalah uji reliabilitas konstruk yang dapat diukur dengan 2 kriteria yaitu composite reliability dan cronbach's alpha. Suatu konstruk dinyatakan reliabel jika nilai composite reliability $>0.60$ (Sari, R. N., \& Sjahruddin, H., 2018). Penelitian ini menggunakan 3 (tiga) variabel laten yaitu variabel pemberdayaan $(\mathrm{X})$, komitmen organisasional $\left(\mathrm{Y}_{1}\right)$ dan kepuasan kerja

Authors : Muhammad Hidayat Taufik dkk. Issue 1 (Agustus, 2018); 82 98

Halaman 88 


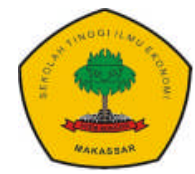

JURNAL ORGANISASI DAN MANAJEMEN

Issue 1 (Agustus, 2018)

https://doi.org/10.31227/osf.io/rfsyx

karyawan $\left(\mathrm{Y}_{2}\right)$. Pengujian composite realibility dalam penelitian dapat

dijelaskan pada tabel 3 dibawah ini:

Tabel 3. Composite Reliability

\begin{tabular}{|l|c|c|c|}
\hline \multicolumn{1}{|c|}{ Composite Reability } & PBD & KO & KK \\
\hline R-Squared & & 0.392 & 0.463 \\
\hline Adj. R-Squared & & 0.380 & 0.442 \\
\hline Composite reliab. & 0.806 & 0.793 & 0.815 \\
\hline Cronbach's Alpha & 0.677 & 0.609 & 0.697 \\
\hline Avg. Var. Extrac & 0.514 & 0.562 & 0.527 \\
\hline Full collin. VIF & 1.679 & 2.111 & 1.794 \\
\hline Q-squared & & 0.397 & 0.464 \\
\hline
\end{tabular}

Sumber: Data diolah (WarpPLS versi 5.0, 2018).

Hasil pada tabel 3 menjelaskan bahwa variabel Pemberdayaan (X) memiliki nilai Composite reliability 0.806> 0.60, variabel Komitmen Organisasional $\left(\mathrm{Y}_{1}\right)$ memiliki nilai Composite reliability $0.793>0.60$ dan variabel Kepuasan Kerja Karyawan $\left(\mathrm{Y}_{2}\right)$ memiliki nilai Composite $r$ reliability $0.697>0.60$ sedangkan untuk nilai Cronbach's Alpha dari ke tiga variabel tersebut memiliki nilai $>0.60$. berdasarkan hasil pengujian tersebut dapat disimpulkan bahwa semua variabel dalam penelitian ini telah memenuhi standar pengujian Composite reliability.

Besaran pengaruh variable pemberdayaan terhadap komitmen organisasi berdasarkan nilai $R$-Squared $=0.392$ dan nilai Q-squared $=0.397$, sementara besaran pengaruh variabel pemberdayaan dan komitmen organisasi terhadap kepuasan kerja berdasarkan nilai $R$ Squared $=0.463$ dan nilai Q-squared sebesar 0.464. Pada analisis partial least square (PLS) besaran pengaruh total ditunjukkan dengan symbol Q-squared, sehingga dapat dinyatakan bahwa kontribusi variabel pemberdayaan dan komitmen organisasi terhadap kepuasan kerja sebesar 0.464 atau sebesar $46,40 \%$ selebihnya yakni sebesar $43,60 \%$ dipengaruhi oleh variabel lain yang tidak diamati, seperti motivasi kerja dan kinerja karyawan.

\section{Evaluasi Model Struktural (Inner Model)}

Tahap selanjutnya dalam penelitian ini adalah evaluasi struktural (inner model) yang meliputi uji kecocokan model (model fit), path coefficient, dan $\mathrm{R}_{2}$. Pada uji kecocokan model terdapat 3 indeks pengujian, yaitu average path

Authors : Muhammad Hidayat Taufik dkk. Issue 1 (Agustus, 2018); 82 98

Halaman 89 


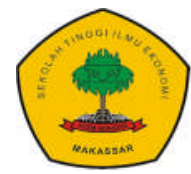

Issue 1 (Agustus, 2018)

https://doi.org/10.31227/osf.io/rfsyx

coefficient (APC), average $R$ - squared (ARS) dan average varians faktor (AVIF) dengankriteria APC dan ARS diterima dengan syarat $\mathrm{p}$ - value $<0,05$ dan AVIF lebih kecil dari 5 (Mahfud Sholihin dan Dwi Ratmono, 2013:61; Wahyudi, T., dkk., 2017).

Tabel 4. Uji Kesesuaian Model

\begin{tabular}{|l|c|c|}
\hline \multicolumn{1}{|c|}{ Pengukuran } & Hasil & Nilai \\
\hline Average path coefficient (APC) & 0.457 & $\mathrm{P}<0.001$ \\
\hline Average R-squared (ARS) & 0.427 & $\mathrm{P}<0.001$ \\
\hline Average adjusted R-squared (AARS) & 0.411 & $\mathrm{P}<0.001$ \\
\hline Average block VIF (AVIF) & 1.552 & $<5$ \\
\hline Average full collinearity VIF (AFVIF) & 1.861 & $<5$ \\
\hline Tenenhaus GoF (GoF) & 0.478 & $<5$ \\
\hline Sympson's paradox ratio (SPR) & 1 & $>0.7$ \\
\hline R-squared contribution ratio (RSCR) & 1 & $>0.9$ \\
\hline Statistical suppression ratio (SSR) & 1 & $>0.7$ \\
\hline Nonlinear bivariate causality direction ratio (NLBCDR) & 1 & $>0.7$ \\
\hline
\end{tabular}

Sumber: Data diolah (WarpPLS versi 5.0, 2018).

Pada tabel 4. diatas menjelaskan bahwa APC memiliki nilai sebesar 0.457 dengan nilai $p$-value $<0.001$, sedangkan ARS mempunyai nilai 0.427 dengan nilai $p$-value $<0.001$, serta nilai AVIF sebesar 1.552 . Berdasarkan kreteria APC dan ARS harus memiliki nilai p-value $<0.05$ dan AVIF nya $<5$. maka dari hasil olah data diatas dapat disimpulkan bahwa Inner Model dapat di terima.

\section{Hasil Uji Hipotesis}

Pengujian hipotesis dalam penelitian ini berdasarkan pada nilai signifikansinya. Tingkat singnifikansi dalam penelitian ini yaitu 5\% atau 0.05 . Berikut disajikan nilai tabel koefisien jalur dan tingkat signifikansi pengaruh antar variabel pada tabel berikut :

Tabel 5. NIlai Path Coefficients dan P-values

\begin{tabular}{|c|c|c|c|c|c|c|c|}
\hline \multicolumn{4}{|c|}{ Path coefficients } & \multicolumn{5}{c|}{ P values } \\
\hline & PBD & KO & KK & & PBD & KO & KK \\
\hline PBD & & & & PBD & & & \\
\hline KO & 0.626 & & & KO & $>0.001$ & & \\
\hline
\end{tabular}

Halaman 90

Authors : Muhammad Hidayat Taufik dkk. Issue 1 (Agustus, 2018); 82 98 
https://doi.org/10.31227/osf.io/rfsyx

\begin{tabular}{|c|c|c|c|c|c|c|c|}
\hline KK & 0.210 & 0.533 & & KK & 0.049 & $<0.001$ & \\
\hline Mediasi & & & 0.334 & Mediasi & & & $<0.001$ \\
\hline
\end{tabular}

Sumber: Data diolah (WarpPLS versi 5.0, 2018).

Keterangan : PBD : Pemberdayaan

KO : Komitmen Organisasional

KK : Kepuasan Kerja Karyawan diajukan :

Berikut ini penjelasan untuk membuktikan hipotesis penelitian yang

$\mathrm{H}_{1}$ Pemberdayaan berpengaruh positif dan signifikan terhadap komitmen organisasional karyawan

Kesimpulan : Mendukung hipotesis disebabkan karena nilai koefisien jalur bertanda positif dengan nilai signifikansi $\mathrm{p}$-value $=$ $<0.05$

$\mathrm{H}_{2}$ Pemberdayaan berpengaruh positif dan signifikan terhadap kepuasan kerja karyawan.

Kesimpulan : Mendukung hipotesis disebabkan karena nilai koefisien jalur bertanda positif dengan nilai signifikansi $p$-value $=<0.05$

$\mathrm{H}_{3}$ Komitmen organisasional berpengaruh positif dan signifikan terhadap kepuasan kerja karyawan.

Kesimpulan : Mendukung hipotesis disebabkan karena nilai koefisien jalur bertanda positif dengan nilai signifikansi $p$-value $=<0.05$

$\mathrm{H}_{4}$ Pemberdayaan berpengaruh positif dan signifikan terhadap kepuasan kerja melalui komitmen organisasional karyawan.

Kesimpulan : Mendukung hipotesis disebabkan karena nilai koefisien jalur bertanda positif dengan nilai signifikansi $\mathrm{p}$-value $=<0.05$

\section{Interpretasi Hasil Penelitian}

Pemberdayaan dapat meningkatkan komitmen organisasional karyawan, pemberdayaan mampu meningkatkan kepuasan kerja karyawan, komitmen organisasional dapat meningkatkan kepuasan kerja karyawan, pemberdayaan dapat meningkatkankepuasan kerja melalui komitmen organisasional karyawan.

\section{a. Pengaruh Pemberdayaan terhadap Komitmen Organisasional Karyawan}

Berdasarkan hasil pengujian Path coefficients sebesar 0,626 dan $p$-values $=0,001<0,05$, maka dapat disimpulkan bahwa pemberdayaan berpengaruh positif dan signifikan terhadap komitmen organisasional karyawan. Koefisien

Authors : Muhammad Hidayat Taufik dkk. Issue 1 (Agustus, 2018); 82 98

Halaman 91 


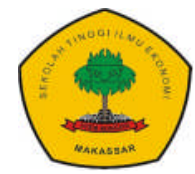

JURNAL ORGANISASI DAN MANAJEMEN

Issue 1 (Agustus, 2018)

\section{https://doi.org/10.31227/osf.io/rfsyx}

jalur bertanda positif menjelaskan bahwa pemberdayaan yang dimiliki karyawan tergolong tinggi.Hal ini disebabkan tingginya arti pekerjaan bagi karyawan dimana karyawan merasa sangat senang dalam menyelesaikan pekerjaan yang dibebankan karena memberikan pelajaran dan pengalaman dalam bekerja dan merasa bertanggung jawab dalam menyelesaikan tugasnya dengan baik.

Besaran nilai $p$-values $=0,001<0,05$. Memiliki arti bahwa pemberdayaan yang dimiliki karyawan terbukti secara nyata mampu memberikan (meningkatkan) komitmen organisasial pada karyawan PT. Pelindo IV (Persero) Terminal Petikemas Makassar. Hal ini disebabkan tingginya arti pekerjaan bagi karyawan dimana karyawan merasa sangat senang dalam menyelesaikan pekerjaan yang dibebankan sehingga karyawan merasa berat meninggalkan perusahaan dan senantiasa memberikan kontribusi yang lebih untuk perusahaan walaupun ada tawaran dari perusahaan lain.

Penyebab lainnya, dapat dijelaskan bahwa karyawan telah memperoleh dan mengalami proses dalam penciptaan kemampuan dan dukungan kepada karyawan serta kesempatan yang diberikan kepada karyawan dalam memperoleh dan meningkatkan keterampilan, pengetahuan, dan kekuasaan yang cukup mempengaruhi kehidupannya dan kehidupan rekan kerja ataupun keluarga yang menjadi perhatiannya. Ditunjukkan dengan kesadaran dalam diri karyawan untuk mengetahui dan memahami arti pekerjaan yang dilakukannya selama ini sehingga karyawan senantiasa berkeinginan untuk mempertahankan keanggotaannya didalam perusahaan. Dibuktikan dengan tingginya kesadaran yang muncul dari dalam diri karyawan untuk berkomitmen dan bertahan dalam organisasi untuk alasan-alasan moral atau etis (seperti, perasaan suka dengan atasan mereka selama ini dan perasaan suka kepada rekan kerja yang merupakan partner kerja mereka) .

Penelitian ini mendukung teori Herzberg (1923); dalam Hurriyati (2018) bahwa tingginya pemberdayaan karena karyawan merasa senang dalam menyelesaikan pekerjaan yang dibebankan sehingga karyawan merasa berat meninggalkan perusahaan ditempatnya bekerja. Hasil penelitian ini sejalan dengan penelitian Nongkeng (2012) bahwa pemberdayaan berpengaruh positif dan signifikan terhadap komitmen organisasional.

\section{b. Pengaruh Pemberdayaan terhadap Kepuasan Kerja Karyawan}

Berdasarkan hasil pengujian Path coefficients sebesar 0,210 dan $p$-values $=0,049<0,05$, maka dapat disimpulkan bahwa pemberdayaan berpengaruh positif dan signifikan terhadap kepuasan kerjakaryawan. Koefisien jalur bertanda positif menjelaskan bahwa pemberdayaan yang dimiliki karyawan tergolong tinggi. Hal ini disebabkan tingginya kompetensi karyawan dimana karyawan mampu menyelesaikan pekerjaan dengan baik, pekerjaan yang diberikan sesuai dengan keahlian yang dimiliki karyawan dan karyawan senantiasa bersikap baik.

Besaran nilai $p$-values $=0,049<0,05$. Memiliki arti bahwa pemberdayaan yang dimiliki karyawan terbukti secara nyata mampu memberikan (meningkatkan) kepuasan kerja pada karyawan PT. Pelindo IV (Persero) Terminal Petikemas Makassar. Hal ini disebabkan kemampuan 


\section{JURNAL ORGANISASI DAN MANAJEMEN}

Issue 1 (Agustus, 2018)

\section{https://doi.org/10.31227/osf.io/rfsyx}

karyawan dalam menyelesaikan pekerjaan yang dibebankan dengan baik dan didukung karyawan memiliki suasana kerja yang harmonis dengan rekan kerja, saling membantu satu-sama lain sehingga karyawan merasa puas dalam bekerja.

Penyebab lainnya, dapat dijelaskan bahwa karyawan telah memperoleh dan mengalami proses dalam penciptaan kemampuan dan dukungan kepada karyawan serta kesempatan yang diberikan kepada karyawan dalam memperoleh dan meningkatkan keterampilan, pengetahuan, dan kekuasaan yang cukup mempengaruhi kehidupannya dan kehidupan rekan kerja ataupun keluarga yang menjadi perhatiannya. Ditunjukkan dengan kesadaran dalam diri karyawan untuk mengetahui dan memahami arti pekerjaan yang dilakukannya selama ini sehingga karyawan merasa adanya kesesuaian antara harapan yang merekan inginkan dengan realita atau kenyataan yang mereka rasakan ditempat kerja, ditunjukkan dengan terjalinnya hubungan yang baik kompak atau harmonis dengan rekan kerja mereka maupun atasan.

Penelitian ini mendukung teori Herzberg (1923); dalam Hurriyati (2018) bahwa tingginya pemberdayaan karena karyawan mampu menyelesaikan pekerjaan dengan baik dan memiliki suasana kerja yang harmonis dengan rekan kerjanya sehingga karyawan puas dalam bekerja. Hasil penelitian ini sejalan dengan penelitian Febriwanti dkk., (2017) bahwa pemberdayaan berpengaruh positif dan signifikan terhadap kepuasan kerja karyawan.

\section{c. Pengaruh Komitmen Organisasional terhadap Kepuasan Kerja Karyawan}

Berdasarkan hasil pengujian Path coefficients sebesar 0,533 dan $p$-values $=0,001<0,05$, maka dapat disimpulkan bahwa komitmen organisasional berpengaruh positif dan signifikan terhadap kepuasan kerja karyawan. Koefisien jalur bertanda positif menjelaskan bahwa komitmen organisasional yang dimiliki karyawan tergolong tinggi. Hal ini disebabkan tingginya komitmen normatif karyawan dimana karyawan bekerja dengan seluruh kemampuan yang dimiliki dan keyakinan karyawan bahwa apa yang dilakukannya sudah sesuai dengan ketentuan yang berlaku sehingga untuk pindah ke perusahaan lain tidak etis bagi karyawan tersebut.

Penyebab lainnya, karena karyawan memiliki keinginan yang tinggi untuk mempertahankan keanggotaannya didalam perusahaan, dibuktikan dengan terjalinnya hubungan yang baik kompak atau harmonis dengan rekan kerja mereka maupun atasan sehingga berdampak pada kekompakan mereka dalam bekerja.

Besaran nilai $p$-values $=0,001<0,05$. Memiliki arti bahwa komitmen organisasional yang dimiliki karyawan terbukti secara nyata mampu memberikan (meningkatkan) kepuasan kerja pada karyawan PT. Pelindo IV (Persero) Terminal Petikemas Makassar. Hal ini disebabkan karyawan bekerja dengan seluruh kemampuan yang dia miliki dan di dukung dengan kondisi penerangan lampu dan cahaya diruangannya baik, lingkungan tempat bekerja sangat nyaman sehingga karyawan sangat puas dalam bekerja.

Halaman 93

Authors : Muhammad Hidayat Taufik dkk. Issue 1 (Agustus, 2018); 82 98 


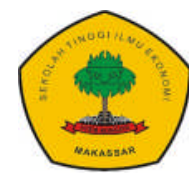

JURNAL ORGANISASI DAN MANAJEMEN

Issue 1 (Agustus, 2018)

\section{https://doi.org/10.31227/osf.io/rfsyx}

Penelitian ini mendukung teori Herzberg (1923); dalam Hurriyati (2018) bahwa tingginya komitmen organisasional karena karyawan mampu menyelesaikan pekerjaan dengan baik dengan segala kemampuan yang dimiliki dan kondisi lingkungan tempat bekerja sangat nyaman sehingga karyawan memiliki kepuasan dalam bekerja. Hasil penelitian ini sejalan dengan penelitian Tilaar dkk., (2014) bahwa komitmen organisasional berpengaruh positif dan signifikan terhadap kepuasan kerja karyawan.

\section{d. Pengaruh Pemberdayaan terhadap Kepuasan Kerja melalui Komitmen Organisasional Karyawan}

Hasil pengujian Path coefficients sebesar 0,334 dan $p$-values $=0,001<$ 0,05 , maka dapat disimpulkan bahwa pemberdayaan berpengaruh positif dan signifikan terhadap kepuasan kerjamelalui komitmen organisasional karyawan. Koefisien jalur bertanda positif menjelaskan bahwa pemberdayaan yang dimiliki karyawan tergolong tinggi. Hal ini disebabkan tingginya kesungguhan karyawan dalam bekerja, kerja sama yang baik yang dilakukan dengan rekan kerja dan kinerja yang dilakukan secara maksimal dapat menciptakan hasil yang mampu memajukan perusahaan. Penyebab lainnya, karena karyawan memiliki keinginan yang tinggi untuk mempertahankan keanggotaannya didalam perusahaan, dibuktikan dengan terjalinnya hubungan yang baik kompak atau harmonis dengan rekan kerja mereka maupun atasan sehingga berdampak pada kekompakan mereka dalam bekerja.

Besaran nilai $p$-values $=0,001<0,05$. Memiliki arti bahwa pemberdayaan yang dimiliki karyawan terbukti secara nyata mampu memberikan (meningkatkan) kepuasan kerjapada karyawan melalui komitmen organisasional PT. Pelindo IV (Persero) Terminal Petikemas Makassar. Hal ini disebabkan tingginya kesungguhan karyawan dalam bekerja karena karyawan diberikan kebebasan dalam mengembangkan kreativitas dalam menyelesaikan pekerjaan yang dibebankan sehingga karyawan tidak merasa tertekan dan membuat karyawan tersebut merasa puas dalam bekerja karena merasa senang dengan pekerjaannya saat ini karena sesuai dengan kemampuan karyawan dan di dukung dengan fasilitas yang diberikan perusahaan sehingga karyawan tersebut memiliki ikatan emosional yang kuat dengan perusahaan dan akan terus berkarir di perusahaan tempat karyawan tersebut bekerja.

Penelitian ini mendukung teori Herzberg (1923); dalam Hurriyati (2018) bahwa tingginya pemberdayaan karena karyawan diberikan kebebasan dalam mengembangkan kreativitas dalam menyelesaikan pekerjaan sehingga karyawan tidak merasa tertekan dan membuat karyawan tersebut merasa puas dalam bekerja sehingga menyebabkan tingginya komitmen karyawan tersebut terhadap perusahaan karena memiliki ikatan emosional yang kuat dengan perusahaan. Hasil penelitian ini sejalan dengan penelitian Yani dkk., (2013) bahwa pemberdayaan berpengaruh positif dan signifikan terhadap kepuasan kerja melalui komitmen organisasional karyawan.

Halaman 94

Authors : Muhammad Hidayat Taufik dkk. Issue 1 (Agustus, 2018); 82 98 


\section{JURNAL ORGANISASI DAN MANAJEMEN}

Issue 1 (Agustus, 2018)

\section{https://doi.org/10.31227/osf.io/rfsyx}

Hasil penelitian ini secara keseluruhan mendukung teori dua faktor (two factor theory) juga dikenal sebaga iteorimotivasi Herzberg atau teori hygiene-motivator Teori ini dikembangkan oleh Frederick Irving Herzberg (1923), bahwa faktor-faktor penentu di tempat kerja yang menyebab kanterjadinya kepuasan dan ketidak puasan kerja, yaitu faktor pemeliharaan (maintenance factors) dan faktor motivasi (motivation factors). Faktor pemeliharaan atau disebut pula dissatifiers, hygiene factors, job context, extrinsic factors. Sedangkan faktor pemotivasian disebut pula satisfier, motivators, job content, intrinsic factors meliputi dorongan berprestasi, pengenalan, kemajuan (advancement), work it self, kesempatan berkembang dan tanggung jawab (Ringgio, 2007; dalam Hurriyati, D. 2018). Bahwa tinggi rendahnya kepuasan kerjakaryawan disebabkan karena faktor pemeliharaan (hygiene factors / dissatisfier), yang dalam penelitian ini dicirikan melalui komitmen organisasional sedangkan faktor pemotivasian (satisfier), dalam penelitian ini ditunjukkan melalui variabel pemberdayaan karyawan.

Beberapa ciri-ciri karyawan yang memiliki kepuasan kerja yang tinggi merasa senang melakukan tugas dalam pekerjaanya, yaitu dengan datang tepat waktu tidak terlambat dan melaksanakan apel pagi dan setelah itu melaksanakan tugas pada unit kerjanya masing-masing (komitmen organisasional).Sedangkan ciri-ciri karyawan yang tidak puasa dalah mereka yang malas berangkat ketempat bekerja dan malas dengan pekerjaanya (pemberdayaan karyawan). Ciri-ciri perilaku karyawan yang memiliki kepuasan kerjaan taralain, tingkah laku karyawan yang malas tentunya akan menimbulkan masalah berupa tingkat absensi yang tinggi, keterlambatan kerja, dan pelanggaran disiplin yang lainnya (Ringgio, 2009; dalam Hurriyati, 2018).

\section{Kesimpulan}

Pemberdayaan berpengaruh positif dan signifikan terhadap komitmen organisasional karyawan. Hal ini disebabkan tingginya arti pekerjaan bagi karyawan dimana karyawan merasa sangat senang dalam menyelesaikan pekerjaan yang dibebankan karena memberikan pelajaran dan pengalaman dalam bekerja dan merasa bertanggung jawab dalam menyelesaikan tugasnya dengan baik sehingga karyawan merasa berat meninggalkan perusahaan dan senantiasa memberikan kontribusi yang lebih untuk perusahaan walaupun ada tawaran dari perusahaan lain.

Pemberdayaan berpengaruh positif dan signifikan terhadap kepuasan kerja karyawan. Hal ini disebabkan tingginya kompetensi karyawan dimana karyawan mampu menyelesaikan pekerjaan dengan baik, pekerjaan yang diberikansesuaidengankeahlian yang dimiliki, karyawan senantiasa bersikap baikdan di dukung karyawan memiliki suasana kerja yang harmonis dengan rekan kerja, saling membantu satu-sama lain sehingga karyawan merasa puas dalam bekerja.

Komitmen organisasional berpengaruh positif dan signifikan terhadap kepuasan kerja karyawan. Hal ini disebabkan tingginya komitmen normative karyawan dimana karyawan bekerja dengan seluruh kemampuan yang dia miliki dan yakin bahwa apa yang dilakukannya sudah sesuai dengan 


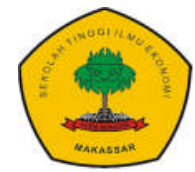

\section{JURNAL ORGANISASI DAN MANAJEMEN}

Issue 1 (Agustus, 2018)

\section{https://doi.org/10.31227/osf.io/rfsyx}

ketentuan yang berlaku sehingga untuk pindah keperusahaan lain tidak etis bagi karyawan tersebut dan di dukung dengan kondisi penerangan lampu dan cahaya diruangannya baik, lingkungan tempat bekerja sangat nyaman sehingga karyawan sangat puas dalam bekerja.

Pemberdayaan berpengaruh positif dan signifikan terhadap kepuasan kerja melalui komitmen organisasional karyawan. Hal ini disebabkan tingginya kesungguhan karyawan dalam bekerja, kerjasama yang baik yang dilakukan dengan rekan kerja serta karyawan diberikan kebebasan dalam mengembangkan kreativitas dalam menyelesaikan pekerjaan yang dibebankan sehingga karyawan tidak merasa tertekan dan membuat karyawan tersebut merasa puas dalam bekerja karena merasa senang dengan pekerjaannya saat ini karena sesuai dengan kemampuan karyawan dan di dukung dengan fasilitas yang diberikan perusahaan sehingga karyawan tersebut memiliki ikatan emosional yang kuat dengan perusahaan dan akan terus berkarir di perusahaan tempat karyawan tersebut bekerja.

\section{Saran}

Pihak PT. Pelindo IV (Persero) Cabang Terminal Petikemas Makassar diharapkan mampu mempertahankan dan mengembangkan pemberdayaan terhadap karyawan agar kepuasan kerjadan komitmen organisasional karyawan dapat lebih meningkat. Kepada pihak manajemen PT. Pelindo IV (Persero) Cabang Terminal Petikemas Makassar untuk meningkatkan kemampuan karyawan dalam bekerja yang diperoleh dari dalam dirinya sendiri (Self-determination) sebagai cerminan dari pemberdayaan karyawan dan peningkatan keinginan karyawan untuk tetap menjadi bagian dari organisasi karena adanya ikatan emosional atau psikologis terhadap perusahaan sebagai cerminan dari komitmen afektif, serta peningkatan jaminan dan kesejahteraan kerja karyawan seperti, sistem dan besaran gaji, jaminansosial, tunjangan dan lain sebagainya sebagai bagian dari kepuasan financial. Hal yang sama pada peningkatan kualitas kerja karyawan utamanya pada faktor yang mempengaruhi kejiwaan karyawan dalam bekerja seperti, minat, ketentraman dalam bekerja, sikap terhadap kerja, bakat dan keterampilan sebagai perwujudan dari Kepuasan psikologi karyawan.

Kepada pegawai bahwa untuk mempertahankan kemampuan karyawan dalam menyesuaikan diri dalam pekerjaan sebagai cerminan dari pemberdayaan karyawan dan meningkatkan kesadaran dalam diri karyawan untuk berkomitmen dan bertahan dalam sebagai bagian dari komitmen organisasional dan menjalin hubungan yang baik kompak dengan rekan kerja, maupun atasan sebagai bagian dari kepuasan kerja. Studi ini merekomendasikan kepada peneliti lanjutan untuk dilakukan pada profesi yang berbeda.

\section{Referensi}

Adhiputra, M. W. (2017). Pengaruh Kepuasan Kerja Dan Komitmen Organisasional Terhadap Kualitas Layanan Hotel. Business Management Journal, 11(2).

Authors : Muhammad Hidayat Taufik dkk. Issue 1 (Agustus, 2018); 82 98

Halaman 96 


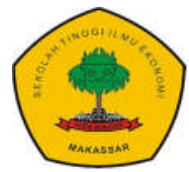

JURNAL ORGANISASI DAN MANAJEMEN

Issue 1 (Agustus, 2018)

https://doi.org/10.31227/osf.io/rfsyx

Akram, M., dan Amsal, C. (2015). Pengaruh komitmen dan disiplin terhadap kepuasan kerja karyawan PT. Wahyuda Abadi Koto Baru. Jurnal Online Mahasiswa (JOM) BidangllmuEkonomi, 1(2), 1-15.

Arishanti, K. I. (2011). Budaya Organisasi, Komitmen Organisasional, Dan Kepuasan Kerja Karyawan. Jurnal Ilmiah Psikologi, 1(1).

Arista, 0. 2015. Pengaruh Persepsiatas Corporate Social Responsbility terhadap Kepuasan Kerja dan Komitmen Organisasi (Survey pada Hotel Bintang V di Yogyakarta) (Doctoral dissertation, FakultasEkonomi).

Augusty Ferdinand. 2011. Metode Penelitian Manajemen Pedoman Penelitian untuk Penulisan Skripsi, Tesis, dan Disertasi Ilmu Manajemen, Edisi 3, AGF Books, Fakultas Ekonomika dan Bisnis Universitas Diponegoro, Semarang.

Barlian, N. A. (2017). Faktor Determinan Kepemimpinan Dan Kepuasan Kerja Karyawan. ASSETS: Jurnal Ilmiah Ilmu Akuntansi, Keuangan Dan Pajak, 1(2), 47-55.

Febriwanti, F., Zulfadil, Z., danSamsir, S. (2017).Pengaruh Kepemimpinan, Fokus pada Konsumen, Pemberdayaan Karyawan, dan Manajemen Proses terhadap Kepuasan Kerja Karyawan PT Telkomsel Area Pekanbaru. Sorot (Jurnal Ilmuilmu Sosial dan Ekonomi), 12(1), 55-70.

Ghozali, Imam. 2012. Aplikasi Analisis Multivariate dengan Program IBM SPSS 20. Semarang: Badan Penerbit - Universitas Diponegoro.

Hurriyati, D. (2018). Kepusan Kerja Ditinjau Dari Perilaku Work Family Conflict. Psikodimensia, 16(2), 180-188.

Lodjo, F. S. (2013). Pengaruh Pelatihan, Pemberdayaan Dan Efikasi Diri Terhadap Kepuasan Kerja. Jurnal EMBA: Jurnal Riset Ekonomi, Manajemen, Bisnis dan Akuntansi, 1(3).

Mahiri, E. A. (2017). Pengaruh Pemberdayaan Karyawan Terhadap Komitmen Organisasional Pada karyawan perusahaan daerah air minum (pdam) kantor pusat majalengka. Maksi, 4(2).

Murty, W. A., dan Hudiwinarsih, G. (2012). Pengaruh kompensasi, motivasi dan komitmen organisasional terhadap kinerja karyawan bagian akuntansi (studi kasus pada perusahaan manufaktur di Surabaya). The Indonesian Accounting Review, 2(02), 215-228.

Nongkeng, H. (2012). Pengaruh Pemberdayaan, Komitmen Organisasional terhadap Kinerja dan Kepuasan Kerja Dosen (Persepsi Dosen Dipekerjakan PTS Kopertis Wilayah IX Sulawesi di Makassar). Jurnal Aplikasi Manajemen, 10(3), 574-585.

Puspitawati, N. M. D., \& Riana, I. G. (2014). Pengaruh kepuasan kerja terhadap komitmen Organisasional dan kualitas layanan. Jurnal Manajemen Strategi Bisnis dan Kewirausahaan, 8(1).

Hasanuddin, R., \& Sjahruddin, H. (2017). The Structure of Emotional Intelligence, Spiritual Intelligence and Its Relationship with Work Enthusiasm and Auditor Performance. World Journal of Business and Management, 3(1), 67.

Samiun, B., Sjahruddin, H., \& Purnomo, S. H. (2017). Pengaruh Pemberdayaan Terhadap Kepuasan Kerja Karyawan.

Sari, R. N., \& Sjahruddin, H. (2018). Pengaruh Kompetensi Terhadap Kinerja Dimoderasi Profesionalisme Karyawan.

Halaman 97

Authors : Muhammad Hidayat Taufik dkk. Issue 1 (Agustus, 2018); 82 98 


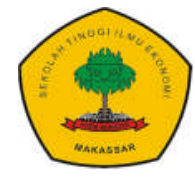

JURNAL ORGANISASI DAN MANAJEMEN

Issue 1 (Agustus, 2018)

https://doi.org/10.31227/osf.io/rfsyx

Sofyan Yamin dan Heri Kurniawan. (2009). Structural Equation Modeling. Jakarta: Salemba Empat.

Sugiyono. (2012). Metode Penelitian Kuantitatif Kualitatif dan R\&D. Bandung: Alfabeta.

Sugiyono. (2013). Metode Penelitian Kuantitatif, Kualitatif dan R\&D. Bandung: Alfabeta.

Sukrajap, M. A. (2017). Pengaruh Kepemimpinan Transformasional Terhadap Kepuasan Kerja Dan Komitmen Organisasional Dengan Dimediasi Oleh Pemberdayaan Psikologis. Jurnal Psikologi, 12(1).

Sunyoto, Danang. (2011). Metodologi Penelitian Ekonomi. CAPS Publishing.Yogyakarta.

Tilaar, R., Mekel, P. A., danTarore, R. N. (2014). Analisis Komitmen Organisasi, Pengembangan Karir dan Pemberdayaan Terhadap Kepuasan Kerja pada Kantor badan Pengelola Perbatasan Kepulauan Sangihe. Jurnal EMBA: Jurnal Riset Ekonomi, Manajemen, Bisnis dan Akuntansi, 2(3).

Wahyudi, T., Sjahruddin, H., \& Gani, M. (2017). Pengaruh Struktur Organisasi Terhadap Efektifitas Kerja Karyawan Pada Pt. Inti Karsa Persada (Kalla Hospitality) Makassar.

Waruwu, P., dan Kom, M. (2013). Pengaruh Pemberdayaan Dan Budaya Organisasi Terhadap Kinerja Pegawai Dengan Mediasi Komitmen Organisasional (Studi pada Kantor Pengawasan dan Pelayanan Bea dan Cukai tipe Madya Cukai Kudus). Penelitian dosen.

Widayanti, K. S., \& Sariyathi, N. K. (2016). Pengaruh Kepuasan Kerja, Pemberdayaan Karyawan, Dan Stres Kerja Terhadap Komitmen Organisasi Pada CV. Akar Daya Mandiri. E-Jurnal Manajemen Unud, 5(11), 7022-7049.

Wijayanti, W. S., Sjahruddin, H., \& Razak, N. (2017). Pengaruh Karakteristik Individu dan Pemanfaatan Teknologi Informasi Terhadap Kinerja Pegawai

Yani, I. M., Supartha, W. G., \& Subudi, M. (2013).Pengaruh Pemberdayaan Dan Kepuasan KerjaTerhadap Komitmen Organisasional Guru Di SMK N 1 Mas Ubud.E-Jurnal Ekonomi dan Bisnis Universitas Udayana.

Authors : Muhammad Hidayat Taufik dkk. Issue 1 (Agustus, 2018); 82 98 